\title{
Siber Zorbalık İle İlgili Haberlerin Türkiye Yazılı Basınında Çerçeveleniși
}

\author{
Bilge Narin ${ }^{1}$ \\ Sevda Ünal ${ }^{2}$
}

Öz

Dijital teknolojiler aracılığıyla bir kimseyi utandıracak, sıkıntıya düşürebilecek kişisel her türlü mesajın yayılması olarak tanımlanan siber zorbalık, enformasyon toplumunun önemli sorun alanlarından biridir. Bu araştırmada, siber zorbalıkla ilgili haberlerin Türkiye'deki ulusal yaygın gazetelerde nasıl çerçevelendiği, bu sayede konuya ilişkin gerçekliğin nasıl inşa edildiği içerik çözümlemesi tekniği ile saptanmaya çalışılmıştır. Haberlerin önemli bir bölümünde, kamuoyunu korkuya sevk edecek, ahlâki panik çerçeve yerine, konuya ilişkin ayrıntıların sıralandığı teknik çerçevenin tercih edildiği saptanmıştır. Haberlerde, soruna ilişkin politikaları destekleyen ya da eleştirel çerçevelerin ise nadiren tercih edildiği gözlenmiştir. Haberlerde siber zorbalık olaylarının sorumluluğu aileler ve eğitmenlere yüklenmiştir. Çalışmanın bulguları iletişim bilimleri disiplini kapsamında gerçekleştirilecek siber zorbalık ve temsil çalışmalarına katkı sağlamaktadır.

Anahtar Sözcükler: Siber Zorbalık, Yeni Medya, Haber Çerçeveleme, Haber Analizi, İçerik Çözümlemesi.

\section{Framing News About Cyberbullying In Turkish Printed Media}

\begin{abstract}
Cyberbullying, as one of the major problems of the information society, can be described as any message that spreads through digital technologies to embarrass or distress someone. The purpose of this research is to investigate the news framing strategies of the national widespread newspapers in Turkey regarding the issue. By doing so, the construction of social reality about cyberbullying is defined through content analysis. According to the news reviewed as samples, moral panic frame is rarely used; but instead the technical frame which includes details about the problem is preferred by the news media. Besides, the supportive or critical frames which target the existing policies about cyberbullying are also rarely brought to the agenda. According to the news contents, families and educators are kept responsible from cyberbullying incidents rather than the police forces. The findings of this research will contribute to the future communication studies about cyberbullying and also media representation.
\end{abstract}

Keywords: Cyberbullying, New Media, News Framing, Analysing News, Content Analysis.

1 Arş. Gör. Dr. Bilge Narin, Gazi Üniversitesi İletişim Fakültesi, Gazetecilik Bölümü 2 Dr. 


\section{Giriș}

Er nformasyon ve iletişim teknolojilerinin kullanımının yaygınlaşması, bu teknolojileri kullananların karșılaşıtıkları sorun alanlarını da beraberinde getirmektedir. Örneğin, çevrimiçi platformlar demokratik işlevleri pekiştirmeleri, eğitimde kullanılabilmeleri ve rasyonel müzakere alanları olmalarının yanı sıra, saldırgan davranışlara yönelik mevcut sorun alanlarını yeniden üreten ve yenilerine neden olan sanal ortamlar olarak da karşımıza çıkmaktadır.

$\mathrm{Bu}$ bağlamda, siber zorbalık enformasyon ve iletişim teknolojilerinin yanlış kullanımından kaynaklanan zararlı sonuçlardan biri olarak kabul edilmektedir (Bhat, Chang ve Linscott, 2010: 36). Özel bir saldırganlık tipi olan siber zorbalık; mobil telefonlar, bilgisayarlar gibi elektronik teknolojiler aracilığıyla ve sosyal medya gibi kanallar üzerinden gerçekleştirilen zorbalık biçimi olarak tanımlanmaktadır. Kavram en basit haliyle toplumsal saldırganlığın diğer türleriyle iç içe geçecek șekilde, İnternet ve diğer dijital teknolojileri kullanarak zararlı içerik gönderme olarak tanımlanmaktadır (Willard, 2007: 265). Bir başka anlatımla, siber zorbalık enformasyon ve iletişim teknolojilerinin bir birey ya da bireylerden oluşan grubu yıldırma, mağdur etme, taciz etme ya da zulmetme gibi amaçlarla kullanılmasıdır (Bhat, 2008: 54).

Zorbalı̆ıın geleneksel diğer türleri gibi siber zorbalık da kasıtlı bir biçimde gerçekleştirilmekte, tekrarlanmakta ve bir güç dengesizliği içerebilmektedir (Kernaghan ve Elwood, 2013). 2000'li yılların başında henüz bir sorun olarak tanımı bile yapılmamış olan kavram, bugün sanal iletişim ortamlarına büyük ölçüde nüfuz etmiş durumdadır. Siber zorbalı̆ın sanal ortamdan kaynaklı anonimlik özelliği nedeniyle, normal şartlarda zorbalık yapmayan kişiler bile, yüz yüze gelmeyecek olmanın rahatı̆̆ına güvenerek bu tür eylemlerde bulunabilmektedir (Poland, 2010). Hatta, geleneksel toplumsal ilişkiler içerisinde etik davranışlar konusunda baskı hisseden kişiler, sanal ortamda bir ekranın ardında gizlenmiş olmalarının verdiği rahatlıkla siber zorbalığa başvurabilmektedir. Bu anlamda, elektronik iletişimin siber zorbalığı besleyen, cesaretlendiren ve de yaygınlaştıran bir doğası bulunmaktadır (Notar, Padgett ve Roden, 2013: 3). Özellikle, İnterneti aktif biçimde kullanan çocuklar ve gençler, siber zorbalık biçimlerine hazırlıksız yakalanmakta ve korumasız kalmaktadır. Onların siber zorbalığa maruz kalma nedenleri fiziksel görünümleri, karakterleri, cinsel yönelimleri veya inanç tercihleri olabilmektedir (Lee, 2016).

Bu araştırmada, siber zorbalıkla ilgili haberlerin Türkiye'de yayınlanan günlük gazetelerde nasıl çerçevelendiğini saptamak amacıyla ideolojik yönelimleri farkı olan ve ulusal ölçekte yayın yapan 27 gazetede, 01 Ocak 2015-01 Temmuz 2016 tarihleri arasında yer alan konu ile ilgili tüm haberler içerik analizine tabii tutulmuştur. Örneklem tüm ulusal basını kapsama iddiasında olduğundan, sonuçların Türkiye yazılı basını özelinde seçili tarihsel dönem için genellenebilir olduğu söylenebilecektir.

Siber zorbalık daha önce Türkiye'de gerçekleştirilen iletişim araştırmalarına konu olmakla birlikte (Arsoy ve Ersoy, 2015; Aktan ve Çakmak, 2015; Akca, Sayımer ve Ergül, 2015; Tamer ve Vatanartıran, 2016), konunun medyada nasıl çerçevelendiğine ilişkin kapsamlı bir çalışma bulunmamaktadır. Söz konusu çalışmalarda sorunun kullanıcı deneyimi ve pratikleri boyutları ele alınmıștır. Örneğin, Kuzey Kıbrıs Türk Cumhuriyeti'nde farkı bölümlerde öğrenim gören üniversite öğrencilerine yönelik bir 
anket çalışmasında, İnternette daha fazla zaman geçiren kişilerin siber zorbalıkla karşılaşma olasılıklarının arttığı ve öğrencilerin yarıdan fazlasının siber zorbalığa maruz kaldığı saptanmıştır (Arsoy ve Ersoy, 2015). Halkla İlişkiler ve Tanıtım Bölümü önlisans ve lisans öğrencilerinin siber zorbalık duyarlııklarının ölçüldüğü bir başka araştırmada ise, genel olarak öğrencilerin siber zorbalık duyarlılıklarının yüksek olduğu ve bu durumun da onların sanal ortamdaki davranışlarını sınırlayıcı etkisi olduğu sonucuna varılmıştır (Aktan ve Çakmak, 2015). Ankara'daki ortaokul öğrencilerinin siber zorbalık deneyimlerine yönelik TÜBITAK destekli projenin sonuçlarında da kız öğrencilerin siber zorbalıkla ilgili davranışları erkek öğrencilere göre daha yüksek oranda onaylamadıkları saptanmıştır (Akca, Sayımer ve Ergül, 2015). Görüldüğü gibi çalışmalar yoğunlukla zorbalık yapan ve zorbalığa uğrayan kullanıcıların deneyimlerine odaklanmaktadır. Yeni medya okuryazarlığı becerilerinin geliştirilmesinin gerekliliği de araştırma sonuçlarında sıklıkla vurgulanmaktadır (Tamer ve Vatanartıran, 2016). Ancak konuya ilişkin bilginin sağlanması ve algının oluşturulmasında etkili olan medyanın konuyu nasıl inşa ettiği sorusunun inmal edilen bir çalışma alanı olduğu gözlenmektedir. Bu bağlamda bu araştırma, alandaki bu boşluğu gidermeyi amaçlamaktadır.

Araştırmada örneklem olarak seçilen haberlere hem "ahlâki panik", "epizodik" (olaysal) ve "tematik" (konusal) çerçeveler gibi genel çerçeveler üzerinden analiz yapılmış; hem de sanal zorbalık ekseninde konuya özel çerçeveler saptanmaya çalışılmıştır. Söz konusu çerçevelerin ne tür anlatılarla kurulduğu, bulgular bölümünde ayrıntılı bir biçimde açıklanmıştır. Çalışmanın bulguları iletişim bilimleri disiplini kapsamında gerçekleştirilecek siber zorbalık çalışmalarına karşılaştırılabilir veriler sunması açısından da önemlidir.

Çalışmada öncelikle siber zorbalıkla mücadelede önemli bir adım olarak kabul edilen yeni medya okuryazarlığı becerilerinden kısaca söz edilmiş; ardından siber zorbalığın basında çerçevelenişi ile ilgili uluslararası yazında yer alan araştırmaların sonuçları özetlenmiştir. Araştırmanın amprik verilerinin yer aldığı son bölümde ise, Türkiye'de gazete haberlerinde konunun ne sıklıkla gündeme getirildiği ve nasıl çerçevelediğine ilişkin bulgular tartışmaya açılmıştır.

\section{Siber Zorbalığı Önlemede Yeni Medya Okuryazarlığı}

İnternet kullanımı çocuklar ve gençler için muazzam fırsatlar sunmaktadır. Çevrimiçi faaliyetler çocuklara ve gençlere kendi kişiliklerini geliştirme, arkadaş edinme ve arkadaşlıklarını sürdürme, yaratıcı içerik oluşturma ve dijital becerileri kazandırma olanağı sağlamaktadır. Ancak, çevrimiçi faaliyetlerin beraberinde getirdiği olumsuzluklar da vardır. Özellikle, çocuklar ve gençler çevrimiçi ortamlarda çok çeşitli risklerle karşılaşabilmektedir. Bu riskler siber zorbalık, zararlı içeriklerle karşılaşma, kişisel verilerin kötüye kullanılması, dolandırıcılığın kurbanı olma, itibarın zarar görmesi ve çevrimiçi cinsel tacize uğrama olarak örneklendirilebilir. İnternet özellikle çocukların ve gençlerin riskli durumlarla karşılaşmalarına aracılık etmesinin yanı sıra, onların aktif bir şekilde riskli davranışlarda bulunmalarına neden olabilecek ortamı da getirmektedir (Berg, 2014: 1). Donegan, Amerikan toplumunda zorbalığın tarihinden yola çıkarak siber zorbalığı ele aldığı çalışmasında, siber zorbalığın çocukları olumsuz etkilediği gibi, bu olumsuz etkilerin hayatları boyunca onların peşini bırakmayacağını da ifade etmektedir (2012: 33). Siber zorbalığın ardındaki nedenler ve kullanılan taktiklere ilişkin veriler, zorbalığa yönelik önleme programlarının artan önemine işaret etmektedir 
(Donegan, 2012: 40). Siber zorbalığa ilişkin yapılan çalışmalarda genel olarak, önleyici programlar ve bu yolla risklerin azaltılması, siber zorbalığı önlemede temel yaklaşım olarak görülmektedir (Donegan, 2012; Akca, Sayımer ve Ergül, 2015, Taiariol, 2010 vb.). Siber zorbalığın önlenmesinde aile ve okulun birincil derecedeki rolü, yaygın ve örgün eğitimde, bilgisayar ya da yeni medya okuryazarlığı konusunda bilinç gelişimi sağlayacak eğitim programları geliştirilmesini öncelemektedir. Bu kapsamda, halihazırda Türk eğitim sisteminde yerini alan medya okuryazarlığı, siber zorbalık risklerine karşı önleyici bir program olarak öne çıkmaktadır. Yeni Medya Okuryazarlığı dersi, bir yandan çocukların teknik becerileri ve kendi ürettikleri içeriklerin etik boyutu konusunda eğitilmelerine olanak sağlarken; diğer yandan da başkaları tarafından üretilen içeriğin güvenilirliğini ve amacını sorgulama yetisi kazandırmaktadır. Böylece, hem çocukların hem de ergenlerin İnternet etiği konusunda bilinçlendirilmesi, saldırgan davranışların azaltılması ve riskli durumlara karşı kendilerini koruyacak yetileri kazanması mümkün hale gelmektedir (Akca, Sayımer ve Ergül, 2015: 84).

Siber zorbalığın önlenmesi için medya okuryazarlığının etkili bir yöntem olacağını savunan Bhat, Chang ve Linscott (2010) ile Sayımer ve Şen (2015)'in, eğitimin kapsamına ilişkin önerileri dikkat çekmektedir. Bhat, Chang ve Linscott'a göre yeni medya okuryazarlığı eğitiminde şunlara dikkat edilmelidir:

a) Siber zorbalığın ve siber zorbalığı oluşturan davranışsal örnek eylem tiplerinin tanımlanması,

b) Siber zorbalık için kullanılan enformasyon ve iletişim teknolojisi türleri ile ilgili bilgi ve anlayış sağlanması,

c) Aktif siber zorbalık, ikincil siber zorbalık, siber zorbalığı gözlemek ve hedefi olmak gibi rollerin öğrenilmesi ve her bir aşmada siber zorbalıkla mücadele için yapılabilecek eylemlerin belirlenmesi (Örneğin açık bir yapılacaklar ve yapılamayacaklar listesi hazırlanması),

d) Her bir teknoloji türü ile ilişkili özel güvenlik ve raporlama biçimlerinin oluşturulması ve öğrenilmesi (Örneğin hem Facebook (2010) hem de MySpace (2010) kapsamlı güvenlik enformasyonuna sahiptir),

e) Öğrencilerin siber zorbalıkla karşılaşırlarsa yapabilecekleri eylemlerin belirlenmesi (Bu eylemler ekran görüntüsü almak, kanıtları basmak, yetişkinlerle konuşmak ve onlara güvenmek, çoğunlukla siber zorbalığı daha da çoğaltacak şekilde intikam almaya kalkışmamak olarak örneklendirilebilir),

f) Siber zorbalığı durdurabilecek davranış örneği eylem tiplerinin gösterilmesi,

g) Bu tür atakların hedefi olanların deneyimledikleri psikolojik etkilerin ve toplumsal zararların anlaşılması,

h) Siber zorbalık durumları için raporlama prosedürlerinin belirlenmesi ve gözlemcilerin siber zorbalıktan kaynaklı rahatsızlığı önlemek için teşvik edilmesi, i) Siber zorbalığa kalkışan kişi ile ilgili net önlemler alınması” (2010: 38-39).

Sayımer ve Şen de (2015) okullarda mevcut olan medya okuryazarlığı dersi müfredatına yeni medya okuryazarlığı eğitiminin dâhil edilmesine yönelik öneriler sunmaktadır. Sayımer ve Şen'e göre eleştirel bir medya okuryazarlığı eğitiminin benimsenmesi ve yaygınlaştırılmasıyla, öğrencilerin yeni medya içeriklerini titizlikle değerlendirme ve yorumlama yetileri gelişecek; böylece, iletileri niteliksel açıdan değerlendirmeleri ile siber zorbalık ve nefret söylemiyle ilgili farkındalıklarının artması mümkün olacaktır. Ayrıca, öğrencilere sosyal ağlardaki profillerini yönetebilmeleri için 
bu sitelerin teknik özelliklerinin uygulamalı olarak öğretilmesi, onların siber zorbalık vakasıyla karşılaştıklarında ilk elden önlem alabilmelerine ve çevrimiçi ortamdaki mahremiyetlerini koruma yollarını öğrenebilmelerine olanak sağlamaktadır.

Özetlersek, yeni medya okuryazarlığı dersi çocukların çevrimiçi etkinliklerde karşılaşabilecekleri olumsuzluklara karşı korunmalarını ve sanal platformların olumlu etkilerinden yararlanmalarını sağlamaktadır. Yeni medya okuryazarlığı, böylece, hem çocuklarda ve ergenlerde hem de genel olarak tüm toplumda siber zorbalığın önlenmesine yönelik bilinç oluşturulmasına katkı sunmaktadır.

\section{Siber Zorbalık ve Haber Çerçeveleme}

Siber zorbalık, son dönemde yaygınlaşan disiplinlerarası bir çalışma alanı olarak karşımıza çıkmaktadır. Milosevic (2015) siber zorbalığın popüler bir çalışma alanı olmakla birlikte, konunun medyada yer alış biçimlerine yönelik araştırmaların (Batacharya, 2004; Ryalls, 2012; Thomas vd., 2011) daha çok tekil (münferit) olaylar üzerine odaklandığına işaret etmektedir. Bu tür bir araştırma tasarımı konunun karmaşıklığı ve çok boyutluluğunu ortaya koymada yetersiz kalmaktadır.

Tekil bir olayın basında yer alış biçiminin analiz edildiği bir araştırmada, Kanada'da uğradığı siber zorbalık nedeniyle intihar eden Rehtaeh Parsons örneklem kabul edilerek; basının konuya yaklaşımında zaman içinde değişen çerçeveler üzerinde durulmuştur. Çalışmada ayrıca, haberler ve köşe yazıları ayrımına gidilerek; suçluya yönelik çerçevenin iki anlatı türünde farklııı gösterdiği saptanmıştır. Haberlerde olay yasaların yetersizliğinden kaynaklanan toplumsal bir sorun olarak çerçevelenirken; yorum yazılarında ise çoğunlukla siber zorbalık sorunundan ziyade failler suçlanmıştır (Felt, 2014). Uluslararası ölçekte siber zorbalıkla ilgili haberlerin doğası ve sıklığının karşılaştırıldığı bir başka araştırmada da nitelikli gazetelerin konuyu daha tarafsız biçimde ele aldıkları ve bu tür yayınlarda ahlâki panik çerçeveye yönelik az sayıda habere rastlandığı saptanmıştır (Vandebosch, Simulioniene, Marczak, Vermeulen ve Bonetti, 2013). Görüldüğü üzere anlatı türleri ve basın kuruluşlarının niteliği konunun ne tür çerçevelerle inşa edildiği üzerinde etkili olabilmektedir.

Amerika'da ana akım medyanın televizyonlarda ve gazetelerde siber zorbalığı hangi çerçevelerle sunduğunun araştırıldığı geniş örneklemli bir çalışmada ise, konunun haberlerde epizodik (olaysal) ya da tematik (konusal) çerçevelerle ele alınışı üzerinde durulmuştur. Epizodik çerçeveleme tekil olaylar, kurbanlar ve faillere odaklanarak parçalı bir anlatı sunarken; tematik çerçeveleme ise kolektif ya da genel kanıtlara odaklanmaktadır (lyengar, 1991: 13-14). Araştırma bulgularında, hem gazetelerde hem de televizyonda epizodik çerçevenin yaygın biçimde kullanıldığı; ancak, televizyon haberlerinin konuyu daha fazla epizodik olarak sundukları saptanmıştır (Televizyonda \%44.1, gazetelerde \%26). Bir başka ifadeyle ABD basınında siber zorbalık, özellikle intiharla sonuçlanan tekil olaylar üzerinden ele alınmakta; siber zorbalığın ardındaki toplumsal ve kültürel faktörler çok az dikkate alınmaktadır. Haberlerde sorunun sorumluluğu ebeveynlerin kontrolüne bırakılırken (Televizyonda \%32.5, gazetelerde \%20) mevcut politikalar ve kurumların sorumluluğuna değinilmemektedir (Milosevic, 2015). Ölümleri siber zorbalıkla bağlantılandırılan dört gençle ilgili Kanada gazetelerinde yer alan haberlerin analiz edildiği bir başka çalışmada ise, gazetelerin siber zorbalığı toplumsal bir sorun olarak çerçeveledikleri saptanmıştır. Haberlerde, sosyal medya 
farkındalık eğitim programlarının hazırlanmasından yeni yasal düzenleme önerilerine kadar farklı çözüm önerilerinin sıralandığı gözlenmiştir (Felt, 2015). Bu araştırmaların sonuçlarına göre, gazetelerin konuya yönelik haber çerçeveleri coğrafi farklılıklara göre şekillenmekte; ülkelerin toplumsal dinamiklerine göre değişiklik gösterebilmektedir.

\section{Amac ve Yöntem}

$\mathrm{Bu}$ çalışma, siber zorbalığa ilişkin haberlerin Türkiye'de ulusal düzeyde yayın yapan gazetelerde hangi haber çerçeveleri aracılığıyla sunulduğunu saptamayı amaçlamaktadır. Siber zorbalık güncel bir sorun alanı olarak, özellikle çocuklarla ilgili haberlere konu olmaktadır. Bu haberlerin siber zorbalığa ilişkin gerçekliği hangi çerçevelerle kurduğunu saptamak, hem temsil hem de yeni medya okuryazarlığı çalışmalarına katkı sağlayacaktır.

Araştırmada siber zorbalığı konu alan haberler analiz edilerek; şu sorulara yanıt aranmıştır:

1- Siber zorbalıkla ilgili haberler hangi sıklıkla yayınlanmıştır?

2- Haberlerin konu çeşitliliği ve kapsamı nasıl kategorize edilebilir?

3- Haberlerin dilsel, içeriksel ve politik çerçeveleri nelerdir?

4- Haberlerde siber zorbalığın sorumlusu olarak kim ya da kimler görülmektedir?

Araştırmada, toplumsal inşacılık yaklaşımı ve çerçeveleme kuramı ekseninde çıkarımlarda bulunmak üzere içerik analizi tekniği kullanılmıştır. Kökenini yorumlayıcı toplum bilimlerinden alan bir yaklaşım olan toplumsal inşacılık; başlıca olarak insanların betimlediği, açıkladığı ve yaşadıkları dünyayı anlamlandırdığı bir süreci (bir başka ifadeyle inşayı) konu edinmektedir (Cheung, 1997: 331). Berger ve Luckman'a göre dil bu toplumsal inşanın temel oluşturucularından biri olarak paylaşılan deneyimleri nesnelleştirmekte ve dilsel topluluk için onları görünür kılmaktadır. Böylece dil, bilginin kolektif olarak saklanmasında hem temel bir amaç hem de araç vazifesi görmektedir (1966: 68). Dilin toplumsal fikirleri şekillendirmede başvurduğu temel metinlerden biri ise haberlerdir.

Kitle iletişim araştırmalarında ortaya konan bazı önermeler şu sonuca varmaktadır: "haber toplumsal olarak inşa edilen bir gerçektir, objektif bir gerçeğin yansıması değildir" (Shoemaker ve Reese, 1996: 21). Haberlerin toplumsal inşasında etkili olan en dikkat çekici faktörlerden birisi de "çerçeveleme"dir. Haber çerçevesi, bir olayla ilgili haberi sunarken kullanılan, haberde nelerin içerileceğini, nelerin dışarıda bırakılacağını belirleyen genel bağlam olarak tanımlanabilir.

“Çerçeveleme" kavramını ilk kez kullanan Goffman'ın ardından, kavramı geliştiren Tuchman, medya çerçevelerine vurgu yapmıştır. Haberle ilgili birçalışmadaçerçeveleme yönteminin uygulanabilirliğini ilk defa Making News adlı çalışmasında ortaya koyan Tuchman, medya çerçevelerinin gündelik yaşam kesitlerini düzenlediğini belirtmiştir (1978: 192). Tuchman'ın çalışması, haberlerin gazetecilerin neyi nasıl yazacaklarıyla ilgili anlık kararlarından ziyade, habere konu olan olayları yazmak için önceden var olan çerçevelerin kullanılmasıyla oluşan bir takım somutlaştırılmış örgütsel rutinler tarafından yönetildiğini göstermektedir. Tuchman çerçeveleme terimini haberlerin inşası sırasında haberdeki rutin prosedürlerin rolünü vurgulamak için kullanmıştır. Bu 
prosedürler sürekli olarak belirli yerlerin ve fikirlerin gösterilmesine yardımcı olurken, diğerlerinin önünü kapatmakta veya onları görünmez kılmaktadır.

Araştırmada, haberler incelenirken çerçeveleme kuramı bağlamında nicel içerik analizi uygulanmıştır. İçerik analizi iletişim içeriğini kategorize ederek, bu kategoriler arasındaki ilişkiselliği sistematize bir biçimde ortaya koyan istatistiki bir yöntemdir (Riffe, Lacy ve Fico, 2005: 3). İçerik analizi büyük metinlerin anahtar özelliklerinin incelenmesi ve belirlenmesi için oldukça uygun olup; haberlerdeki uzun süreli değişikliklerin ve eğilimlerin sistematik olarak planının çıkarılmasına olanak sağlamaktadır (Hansen, 1998: 123-124).

\section{Evren ve Örneklem}

Bu araştırmanın örneklemi 01 Ocak 2015 - 01 Temmuz 2016 tarihleri arasında Türkiye'de ulusal ölçekte yayın yapan 27 gazetede yayınlanan toplam 93 haberdir. Örneklem, Türkiye'deki gazetelerin siber zorbalık konusunu ne sıklıkla gündeme getirdiğini ve hangi dilsel, içeriksel ve politik çerçevelerle sunduğunu ortaya koyma amacıyla seçilmiştir. Söz konusu örneklem Basın İlan Kurumu tarafından yayınlanan süreli yayınlar listesinde yer alan (http://www.bik.gov.tr/gazeteler/) ilân ve reklam verilebilecek tüm ulusal yazııı basın kuruluşularını kapsadığından, Türkiye özelinde verili tarihsel dönem için genellenebilir sonuçlar sağlamaktadır.

\section{Veri Toplama ve İșlem}

Araştırmada, örneklem olarak kabul edilen haber metinlerine ticari bir medya takip sitesinin aracılığıyla ulaşıımıştır. Söz konusu takip merkezinin haber arama arayüzünde "siber zorbalık", "sanal zorbalık" ve "zorbalık" sözcükleri kullanılarak tarama yapılmış, konu ile ilgili olduğu saptanan 93 haber araştırma kapsamına dahil edilmiştir.

Söz konusu haberin içeriklerine dair veriler hazırlanan kodlama yönergesine göre SPSS programına kodlanarak oluşturulmuş ve tablolaştırılmıştır. Sonuçların güvenilirliğini sağlamak adına, araştırmaçlar örneklemi ikinci kez kodlayarak hataları ayıklamıştır. Kodlama yönergesinde haberde geçen hangi ifadelerin ne tür çerçeve kategorileri olarak kabul edileceği açıkça belirtilmiştir. Başka bir anlatımla her bir çerçeve kategorisi için hangi sözcüklerin ve ifadelerin ipucu olabileceği yönergede açıklanmıştır. Örneğin, bir haber başlığında ünlem işareti kullanılmışsa veya metinde "dikkat", "kabus", "çaresizlik" gibi paniği körükleyecek ifadeler yer alıyorsa; söz konusu haberde "ahlâki panik çerçeve"nin dolaşıma sokulduğu varsayılmıştır. Böylece aynı verileri analiz edecek olası üçüncü bir araştırmacının da benzer kodlama yapabilmesi sağlanmıştır.

\section{Bulgular}

$\mathrm{Bu}$ başlık altında, araştırma bulguları haberlerin sıklığı, kapsamı, konusu, dilsel, içeriksel ve politik çerçeveleri, siber zorbalığın sorumlularına ilişkin göndermeler ve haberin geçtiği coğrafya başlıkları altında ayrı ayrı analiz edilmiştir. Siber zorbalıkla ilgili haberlerin ne sıklıkta yayınlandığı ve hangi çerçevelerle inşa edildiği sorgulandığında, konunun Türkiye basınında gerektiği kadar büyük bir ilgiyle gündemde yer bulmadığı gözlenmektedir. 
Tablo 1. Gazetelerde Yer Alan Siber Zorbalıkla İlgili Haber Sayısı

\begin{tabular}{|c|c|c|}
\hline Gazete Adı & Haber Sayısı & Yüzde \\
\hline Milliyet & 18 & 19,4 \\
\hline Hürriyet & 11 & 11,8 \\
\hline Sabah & 8 & 8,6 \\
\hline Sözcü & 8 & 8,6 \\
\hline Habertürk & 7 & 7,5 \\
\hline Vatan & 4 & 4,3 \\
\hline Akșam & 3 & 3,2 \\
\hline Türkiye & 3 & 3,2 \\
\hline Yeniçağ & 3 & 3,2 \\
\hline Birgün & 3 & 3,2 \\
\hline Cumhuriyet & 3 & 3,2 \\
\hline Posta & 2 & 2,2 \\
\hline Yeni Akit & 2 & 2,2 \\
\hline Yeni Asya & 2 & 2,2 \\
\hline Yurt & 2 & 2,2 \\
\hline Dokuz Sütun & 2 & 2,2 \\
\hline Dünya & 2 & 2,2 \\
\hline Güneș & 1 & 1,1 \\
\hline Star & 1 & 1,1 \\
\hline Taraf & 1 & 1,1 \\
\hline Anayurt & 1 & 1,1 \\
\hline Yeni Șafak & 1 & 1,1 \\
\hline Yeni Söz & 1 & 1,1 \\
\hline Gün Boyu & 1 & 1,1 \\
\hline Aydınlık & 1 & 1,1 \\
\hline Diriliș Postası & 1 & 1,1 \\
\hline Evrensel & 1 & 1,1 \\
\hline Total & 93 & 100,0 \\
\hline
\end{tabular}

Tablo-1'de yer alan verilere göre Türkiye'de ulusal çapta günlük yayınlanan toplam 27 gazetede, bir yılı aşkın süre içinde, siber zorbalığa ilişkin 93 haber yayınlandığı gözlenmektedir. Anadamar medyanın popüler medya kuruluşlarının, konuyu diğer gazetelere oranla daha sık gündeme getirdikleri görülmektedir. Son kertede, siber zorbalık sorununun basın kuruluşlarınca sıklıkla ele alınan konulardan biri olmadığı söylenebilecektir. Bu durumun temel nedenlerinden biri, Türkiye'de intihar vakası gibi ölümcül sonuçları olan tekil siber zorbalık olaylarının gerçekleşmemiş ya da resmi kayıtlara geçmemiş olmasıdır. 
Tablo 2. Haberlerin Kapsamı

\begin{tabular}{|c|c|c|}
\hline Haberin Kapsamı & Haber SayıII & Yüzde \\
\hline Genel & 87 & 93,5 \\
\hline Tekil Olay & 4 & 4,3 \\
\hline Hem Tekil Olay Hem de Genel & 2 & 2,2 \\
\hline Toplam & 93 & 100 \\
\hline
\end{tabular}

Haberlerin kapsamı incelendiğinde, büyük oranda yaşanmış tekil bir siber zorbalık olayı yerine sorunun genel boyutlarıyla ele alınıp işlendiği görülmektedir (\%93,5). Haberler, siber zorbalığı daha çok gün geçtikçe etkinlik alanını arttıran ve kolayca saptanamayan toplumsal bir sorun olarak ele almaktadır. Çünkü, Türkiye'de kamuoyunun gündemine taşınmış, büyük çaplı ve kayıtlı bir siber zorbalık olayı bulunmamaktadır. Az sayıdaki tekil olayı konu alan haberde de $(\% 4,3)$ yurt dışında yaşanan popüler siber zorbalık örnekleri kamuoyunun gündemine taşınmıştır. Bir başka anlatımla, tekil olayları konu alan haberler, hack skandalı nedeniyle intihar eden gençler gibi somut öznel olaylara değinirken; genel kapsamlı haberlerde ise siber zorbalığın psikolojik ve sosyolojik boyutları, siber zorbalıktan korunma ve mücadele yöntemleri ile çözüm politikaları gibi konular üzerinde durulmuştur.

Tablo 3. Haberlerin Konusu

(Konu sayısı birden fazlaysa çoklu kodlama yapılmıștır)

\begin{tabular}{|c|c|c|}
\hline Haberin Konusu & Haber Sayısı & Yüzde \\
\hline Teknoloji & 93 & 100 \\
\hline Çocuk & 77 & 82,8 \\
\hline Eğitim & 46 & 49,5 \\
\hline Uzman Görüșü & 43 & 46,2 \\
\hline Cözüm Önerileri & 37 & 39,8 \\
\hline Politika & 36 & 38,7 \\
\hline Bilimsel Etkinlik & 23 & 24,7 \\
\hline Sosyal Kampanya & 10 & 10,8 \\
\hline Diğer & 3 & 3,2 \\
\hline
\end{tabular}

Haberler konularına göre ayrıştırılı̆̆ında en çok teknoloji ve çocuk konularının gündeme getirildiği gözlenmektedir (\%100; \%82,8). Siber zorbalıkla mücadelede eğitimin yeri ve önemi yine sıklıkla tekrarlanan bir haber konusu olarak karşımıza çıkmaktadır $(\% 49,5)$. Konuyla ilgili uzmanların görüşleri, çözüme yönelik öneriler ve politikalar, bilimsel etkinlikler ve sosyal kampanyalar ise diğer haber konuları olarak gündeme taşınmaktadır.

Soruna yönelik çözüm önerileri incelendiğinde; İnternetin yasaklanması yerine aile içerisinde sırayla kullanılması, özellikle çocukların kullanımına süre sınırı getirilmesi ve kullanımın denetlenmesi, çocuklara yönelik İnternet ve bilgisayar okuryazarlığı eğitimleri aracılığıyla bilinçli ve güvenli İnternet kullanımının sağlanması ile gerçek toplumsal yaşam içinde ailevi ilişkilerin güçlendirilmesinin sıklıkla vurgulandığı gözlenmektedir. 
Tablo 4. Haberlerin Dilsel Çerçevesi

\begin{tabular}{|c|c|c|}
\hline Dilsel Çerçeve & Haber SayıII & Yüzde \\
\hline Teknik & 63 & 67,7 \\
\hline Ahlâki Panik & 18 & 19,4 \\
\hline Hem Ahlâki Panik Hem Teknik & 12 & 12,9 \\
\hline Toplam & 93 & 100 \\
\hline
\end{tabular}

Toplumsal bir inşa olan ahlâki panik çerçeve, toplumun var olan korkularını ve kaygılarını yeniden üreterek pekiştirir. Yeni medya ortamına yönelik bu tür çerçevelerin dolaşıma sokulması nedeniyle asıl sorunlar kamuoyunun gündemine ya eksik ve yetersiz olarak getirilmekte ya da hiç getirilmemektedir (Binark, 2012). Siber zorbalık özelinde ele aldığımızda ahlâki panik çerçeve, konuyu haber metinlerinde bir toplum içinde kişilerin uymak zorunda oldukları kurallara uygunluk açısından sorgulayan; çoğu kez soruna ilişkin panik havası yaratacak şekilde "sapıklar", "dikkat", "dehşet" ve "tehdit" gibi tepkisel nitelemeler içeren haber çerçevesidir. Teknik çerçeve ise olaya ilişkin tepkisel nitelemelerde bulunmak yerine; konunun gündeme geldiği mekân, coğrafya ve zaman gibi ayrıntılara ilişkin bilgiler içermektedir.

$\mathrm{Bu}$ araştırma kapsamında, haber dilindeki çerçeveleri sorguladığımızda, haberlerin büyük bir bölümünün $(\% 67,7)$ teknik bir çerçeve ile yazıldığı gözlenmektedir. Haberlerin \%19,4'ünde ise ahlâki panik çerçeve kullanılarak, soruna ilişkin panik havası yaratılmıştır. Bu tür anlatılar kamuoyunu korkuya sevk ederek; tepkisel, sansürcü, baskıcı politika ve tutumlara neden olabilmektedir.

Ahlâki panik çerçevenin yaratabileceği olumsuz sonuçlar, başkaca araştırmalara da konu olmuştur. Olweus, medyanın özellikle zorbalığın bu özel türünün gündemde fazlaca yer tutmasını eleştirerek, bu vurgunun büyük ölçüde abartılı olduğunu ve bilimsel araştırmalara dayanmadığını iddia etmektedir. Bu çerçevenin yaratabileceği talihsiz sonuçlara da değinen yazar, gerçeğin çarpıtılmış ve abartılı tasvirinin aileler, öğretmenler ve belki de çocuklar üzerinde gereksiz anksiyete ve gerginliğe yol açabileceğinin altını çizmiştir. Ayrıca bu abartılı ilgi diğer geleneksel zorbalık biçimlerinin önemsizleştirilmesine ve zorbalıkla mücadelede odak kaymasına neden olabilmektedir (2012: 521 ve 535). Bu bağlamda, Türkiye'deki gazetelerin haber metinlerinde panik havası yaratmak yerine teknik çerçeveyi daha sık kullanmaları medya etiği açısından olumlu olarak değerlendirilebilecektir.

Tablo 5. Haberlerin İçerik Çerçevesi

\begin{tabular}{|c|c|c|}
\hline İçerik Çerçeve & Haber Sayısı & Yüzde \\
\hline Tematik (Konusal) & 84 & 90,3 \\
\hline Epizodik (Olaysal) & 6 & 6,5 \\
\hline Hem Tematik Hem Epizodik & 3 & 3,2 \\
\hline Toplam & 93 & 100 \\
\hline
\end{tabular}

Tablo 5'te tematik (konusal) ve epizodik (olaysal) çerçeve ayrımı yapılmıştır. Haberlerde bağlama ilişkin bilgi veren, diğer olaylarla bağlantı kuran, kısaca daha çok emek isteyen çerçeve türüne tematik çerçeve denilmektedir (Asley ve Olson, 1988: 264270). Bunun yerine yüzeysel ve anlık bilgilerin kullanıldığı çerçeve ise "epizodik" olarak 
adlandırılmaktadır. İncelenen dönemdeki gazeteler göz önüne alındığında, haberlerin $\% 90,3$ 'ünde tematik çerçevenin tercih edildiği gözlenmektedir. Bu durum olumlu olarak değerlendirilebilecektir. Çünkü, tematik çerçeveli haberler konunun bağlamını, tarihsel gelişimini, mücadele ve çözüm yollarını tartışmaya açmaktadır.

Tablo 6. Haberlerin Politik Çerçevesi

\begin{tabular}{|c|c|c|}
\hline Politik Çerçeve & Haber SayıSI & Yüzde \\
\hline Somut Verilere Dayalı & 16 & 17,2 \\
\hline Eleștiren & 7 & 7,5 \\
\hline Destekleyen & 5 & 5,4 \\
\hline Kodlama Yapılamıyor & 65 & 69,9 \\
\hline Toplam & 93 & 100 \\
\hline
\end{tabular}

Siber zorbalık ile ilgili politik bir çerçeve içeren haber sayısı oldukça azdır $(\% 30,1)$. Konu, haberlerde çoğunlukla, mevcut resmi politikalardan bağımsız bir biçimde toplumsal ya da münferit bir sorun olarak işlenmektedir $(\% 69,9)$. Politik çerçeve içeren az sayıda haberin önemli bir bölümü $(\% 17,2)$ siber zorbalıkla mücadele konusunda gerçekleştirilen bilim ve eğitim politikaları ya da hukuki düzenlemeler gibi somut verilere dayalı ayrıntıları içermektedir. Yine bu politikaları eleştiren az sayıda haberde $(\% 7,5)$ eğitim politikalarının yetersizliği ve yasalardaki boşluk üzerinde durulmaktadır. Politik çerçeve içeren haberlerin azlığı, soruna ilişkin sorumluluğun haberlerde kim ya da kimlere yüklendiği sorusunu da beraberinde getirmektedir. Bu konu aşağıdaki tabloda incelenmiştir.

Tablo 7. Siber Zorbalığın Sorumlusu

(Haberde ișaret edilen sorumlu birden fazlaysa çoklu kodlama yapılmıștır)

\begin{tabular}{|c|c|c|}
\hline Sorumlu & Haber Sayısı & Yüzde \\
\hline Aileler & 43 & 46,2 \\
\hline Eğitim Sistemi & 28 & 30,1 \\
\hline Toplumsal Yozlașma & 4 & 4,3 \\
\hline Hukuki Yetersizlikler & 4 & 4,3 \\
\hline Teknoloji & 2 & 2,2 \\
\hline Failler & 2 & 2,2 \\
\hline
\end{tabular}

Haberlerde siber zorbalık mağduriyetlerinin sorumlusu olarak kim ya da kimlerin işaret edildiğine bakıldığında, en çok $(\% 46,2)$ ailelerin suçlandığı gözlenmektedir. Haber metinlerinde çocukların sanal ortamda geçirecekleri sürenin niteliği ve sorumluluğu büyük ölçüde ailelere yüklenmiş durumdadır. Eğitim sistemindeki aksaklıklar $(\% 30,1)$ ikincil sorumlu olarak karşımıza çıkmaktadır. Sorunun çözümünde eğiticilere de sorumluluk düştüğü ve yeni medya okuryazarlığı derslerine duyulan ihtiyaç bu kategoride sıklıkla tekrarlanan haber konularıdır. Siber zorbalığın toplumsal yozlaşma ve hukuki yetersizliklerden kaynaklanan bir sorun olduğu da az sayıda haberde dile getirilmektedir. Yine az sayıda haberde $(\% 2,2)$ sorumlu bizatihi teknolojinin kendisi olarak betimlenmekte; siber zorbalığa maruz kalınan sosyal medya kanalları güvenliği 
sağlayamadıkları gerekçesiyle eleştirilmektedir.

Tablo 8. Habere Konu Olan Coğrafya

\begin{tabular}{|c|c|c|}
\hline Coğrafya & Haber Sayısı & Yüzde \\
\hline Ulusal & 69 & 74,2 \\
\hline Uluslararası & 16 & 17,2 \\
\hline Hem Ulusal Hem Uluslararası & 8 & 8,6 \\
\hline Toplam & 93 & 100 \\
\hline
\end{tabular}

Haberlerin \%74,22'sinin ulusal bir coğrafyayı kapsaması haber değeri etmenlerinden "yakınlık"ı akla getirmektedir. Yakınlık öğesi, insanların doğalarından kaynaklanan bir özelliği açıklamaktadır. İnsanlar doğaları gereği, yakın çevrelerinde olan olaylarla ilgilenir ve bunlara karşı daha fazla merak duyarlar (Yüksel ve Gürcan, 2005: 59). $\mathrm{Bu}$ nedenle, araştırma kapsamında incelenen haberlerde, siber zorbalık sorunu, çoğunlukla ulusal bir perspektifte ele alınmış; siber zorbalığa ilişkin uluslararası olaylar ve sorunlar nadiren haberlere konu olabilmiştir.

\section{Sonuc}

Enformasyon çağının yol açtığı toplumsal bir sorun olan siber zorbalık, Türkiye'de basın kuruluşlarında farklı çerçevelerle gündeme getirilen bir konudur. Konunun gazetelerde belirli çerçevelerle sunumu; sorumlular ve bağlama ilişkin gerçekliğin farklı biçimde inşa edilmesine neden olmaktadır.

Türkiye'de ulusal ölçekte yayın yapan tüm gazetelerde bir yılı aşkın süreyle yayınlanan siber zorbalıkla ilgili tüm haberlerin analiz edildiği bu çalışmada; konunun büyük oranda genel bir toplumsal sorun olarak görüldüğü saptanmıştır. Siber zorbalık haberlerde psikolojik ve sosyolojik boyutlarıyla ele alınmış ve korunma yöntemleri uzman görüşleri ile desteklenerek sunulmuştur.

Sıklıkla "teknoloji" ve "çocuk" bağlamına oturtulan haberlerde; toplumu korkuya sevk edebilecek ahlâki panik çerçevenin nadiren kullanıldığı gözlenmiştir. Bu tür bir haber inşası tepkisel, sansürcü ve baskıcı politikalara neden olabileceğinden; gazeteler tarafından bu çerçevenin yaygın biçimde kullanılmaması olumlu olarak nitelendirilebilecektir. Benzer biçimde yüzeysel ve anlık bilgiler veren epizodik çerçeve yerine, tarihsel ve toplumsal bağlama ilişkin geniş perspektifli bir tartışma ortamı sağlayan tematik çerçevenin yaygın olarak kullanılması da olumlu olarak nitelenebilecek bir diğer sonuç olarak karşımıza çıkmaktadır.

Ancak siber zorbalık sorununa ilişkin resmi devlet politikasına yönelik tutum incelendiğinde, haber çerçevelerinde nadiren mevcut politikaların eleştirildiği ya da desteklendiği görülmüştür. Çünkü haber metinlerinde sorunun sorumluluğu öncelikli olarak ailelere sonra da eğitimcilere yüklenmiştir. Hukuki yetersizlikler ile sosyal medya kanallarının güvenlik açıklarına ilişkin bilgiler, haberlerde seyrek biçimde değinilen ayrıntılar olarak karşımıza çıkmaktadır. Oysa teknolojik, toplumsal, psikolojik, hukuki ve etik pek çok boyutu bulunan siber zorbalık olaylarının çözümünün yalnızca ailelerin ve eğitimcilerin sorumluluğuna bırakılması, soruna dair eksik bir kavrayışa 
neden olmaktadır. Haber kuruluşlarının, sorumlu bir habercilik anlayışıyla, konuya iliş̧in ulusal ve uluslararası politikaları takip eden ve onları karşılaştıran analizlere yer vermeleri, siber zorbalığı önleme açısından önemli olacaktır.

Siber zorbalık, başta çocuklar ve gençler olmak üzere toplumun tüm kesimlerini tehdit eden bir sorun olarak güncelliğini korumaktadır. Bu çalışmanın sonuçlarının siber zorbalıkla ilgili uluslararası karşılaştırmalı medya temsil çalışmalarına katkı sağlayabileceği değerlendirilmektedir.

\section{Kaynakça}

Akca, Emel Baştürk; Sayımer, İdil ve Ergül, Seda (2015). "Ortaokul Öğrencilerinin Sosyal Medya Kullanımları ve Siber Zorbalık Deneyimleri”, Global Media Journal Tr Edition, Spring, 5(10): 7186.

Aktan, Ercan ve Çakmak, Veysel (2015). "Halkla Illişkiler Öğrencilerinin Sosyal Medyadaki Siber Zorbalık Duyarıııılarını Ölçmeye Illişkin Bir Araştırma”, Gümüşhane Üniversitesi Illetişim Fakültesi Elektronik Dergisi, Eylül, Cilt:3, Sayı:2: 159-176.

Arsoy, Aysu ve Ersoy, Metin (2015). "Üniversite Öğrencilerinin Sosyal Ağlardaki Siber Zorbalık Tutum ve Davranışları" içinde İletişim Çalışmaları 2015, ed. Aydın Ziya Özgür, Aytekin İşman, Sakarya Üniversitesi Yayını, No:134, Sakarya: 353-368.

Batacharya, Sheila (2004). "Racism, 'Girl Violence', And The Murder Of Reena Virk”, içinde Christine Alder \& Anne Worrall (Ed.), Girls' Violence: Myths And Realities, New York: State University of New York Press: 61-80.

Berg, Bibi van den (2014). "Introduction", içinde Simone van der Hof, Bibi van den Berg \& Bart Schermer (Ed.), Minding Minors Wandering The Web: Regulating Online Child Safety, Netherlands: T.M.C. Asser Press: 1-16.

Berger, Peter L., Luckmann, Thomas (1966). The Social Construction of Reality: A Treatise in the Sociology of Knowledge, Anchor Boks, New York.

Bhat, Christine Suniti (2008). "Cyber Bullying: Overview and Strategies for School Counsellors, Guidance Officers, and All School Personnel", Australian Journal of Guidance and Counselling, 18(1): 53-66.

Bhat, Christine Suniti; Chang, Shih-Hua ve Linscott, Jamie A. (2010). "Addressing Cyberbullying as a Media Literacy Issue", New Horizons in Education, Vol.58, No.3, Dec 2010: 34-43.

Binark, Mutlu (2012). "Yeni Medya Okuryazarlığı”, I. Uluslararası Teknoloji Bağımlıı̆ğı Konferansı Bildiri Tam Metinleri Kitabı, İstanbul: Ümraniye Belediyesi Yayınevi.

Cheung, Maria (1997). "Social Construction Theory and The Satir Model: Toward a Synthesis", The American Journal of Family Theraphy, Winter, Vol. 25, No.4: 331-343.

Donegan, Richard (2012). "Bullying and Cyberbullying: History, Statistics, Law, Prevention and Analysis", Elon Journal Of Undergraduate Research in Communications, Vol.3, No.1: 33-42. 
Felt, Mylynn (2014). "Framing "Cyberbullying": Competing Frame Coverage of Rehtaeh Parsons' Death!", içinde Aiden Buckland ve Caroline Caron (Ed.), TEM 2014: Proceedings of the Technology \& Emerging Media Track: 1-9.

Felt, Mylynn, (2015). "The Incessant Image: How Dominant News Coverage Shaped Canadian Cyberbullying Law”, UNB Law Journal, Vol/Tome 66: 137-160.

Hansen, Anders (1998). "Content Analysis", Mass Communicaiton Research Methods, içinde Anders Hansen, Simon Cottle, Ralph Repline \&Chris Newbold (Ed.), New York: New York University Press.

lyengar, Shanto (1991). Is Anyone Responsible: How Television Frames Political Issius, The University of Chigago Press.

Kernaghan, Donna, Elwood, Janette (2013). "All The (Cyber) World's A Stage: Framing Cyberbullying As A Performance". Cyberpsychology: Journal of Psychosocial Research on Cyberspace, 7(1), Article 5.

Lee, Changho (2016). "Cyberbullying among Korean adolescents: prevalence, predictors, and policy", IAMCR 2016 International Communication Section, Abstracts Of Papers Accepted For Presentation At The Annual Conference Of The International Association for Media and Communication Research, Leicester, UK, 27-31 July 2016.

Milosevic, Tijana (2015). "Cyberbullying In Us Mainstream Media”, Journal of Children and Media, Vol. 9, No. 4: 492-509.

Notar, Charles E.; Sharon Padget ve Jessica Roden (2013). "Cyberbullying: A Review of the Literature", Universal Journal of Educational Research, 1(1): 1-9.

Olweus, Dan (2012). "Cyberbullying: An overrated phenomenon?", European Journal of Developmental Psychology, 9 (5): 520-538.

Poland, Scott (2010). "Cyberbullying Continues To Challenge Educators", District Administration, 46(5): 55.

Riffe, Daniel, Lacy, Stephen, Fico, Frederick (2005). Analyzing Media Messages: Using Quantitative Content Analysis In Research, New Jersey: Lawrence Erlbaum Associates, Inc.

Ryalls, Emily (2012). "Demonizing "Mean Girls" In The News: Was Phoebe Prince "Bullied To Death?", Communication, Culture \& Critique, 5: 463-481.

Sayımer, İdil, Şen, Fatma Nur (2015). Okulda Siber Zorbalığın Önlenmesinde Yeni Medya Okuryazarlığı Eğitiminin Önemi: Medya Okuryazarlığı Müfredatı İçin Öneriler, Yeni Medya Çalışmaları II. Ulusal Kongre, 26-27 Şubat: 634-651.

Shoemaker, Pamela J. ve Stephen D. Reese (1996). Mediating the Message: Theories of Influences on Media Content, White Plains, New York: Longman.

Taiariol, Jennifer (2010). Cyberbullying: The Role Of Family And School, Michigan: Wayne State University (Yayınlanmamış Doktora Tezi). 
Tamer, Nurseli ve Vatanartıran, Sinem (2016). "Ergenlerin Teknolojik Zorbalık Algıları ve BunaYönelik Teknolojik Zorbalık Farkındalığı Eğitimi: Pilot Uygulama”, Yeni Medya Çalışmaları II. Ulusal Kongre Kitabı, Alternatif Bilişim Derneği: 54-66.

Thomas, K. Edwards, Nakarada-Kordic, Ivana, McKenna, Brad, O'Brien, Anthony \& Nairn, Raymond (2011). "Suicide Online: Portrayal Of Website-Related Suicide By The New Zealand Media", New Media and Society, 13: 1355-1372.

Tuchman, Gaye (1978). Making News: A Study In Construction of Reality, New York: The Free Press.

Vandebosch, Heidi; Simulioniene, Roma; Marczak, Magdalena; Vermeulen Anne; Bonetti, Luigi (2013). "The Role of the Media", içinde P.K. Smith \& G. Steffgen (ed.), Cyberbullying Through the New Media: Findings from an international network, London: Psychology Press: 99-118.

Willard, E. Nancy. (2007). Cyberbullying And Cyberthreats: Responding To The Challenges Of Online Social Aggression, Threat And Distres, USA: Research Press.

Yüksel, Erkan ve Gürcan, Halil İbrahim (2005). Haber Toplama ve Yazma, Konya: Tablet Kitapevi. 